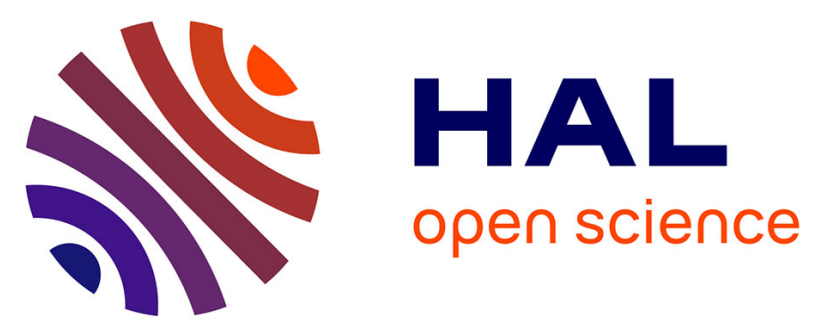

\title{
In Situ Generated Ruthenium-Arene Catalyst for Photoactivated Ring-Opening Metathesis Polymerization through Photolatent N-Heterocyclic Carbene Ligand
}

Julien Pinaud, Thi Kim Hoang Trinh, David Sauvanier, Emeline Placet, Sriprapai Songsee, Patrick Lacroix-Desmazes, Jean-Michel Becht, Bassam Tarablsi, Jacques Lalevee, Loïc Pichavant, et al.

\section{- To cite this version:}

Julien Pinaud, Thi Kim Hoang Trinh, David Sauvanier, Emeline Placet, Sriprapai Songsee, et al.. In Situ Generated Ruthenium-Arene Catalyst for Photoactivated Ring-Opening Metathesis Polymerization through Photolatent N-Heterocyclic Carbene Ligand. Chemistry - A European Journal, 2018, 24, pp.337-341. 10.1002/chem.201705145 . hal-01678320

\section{HAL Id: hal-01678320 \\ https://hal.science/hal-01678320}

Submitted on 10 Jan 2018

HAL is a multi-disciplinary open access archive for the deposit and dissemination of scientific research documents, whether they are published or not. The documents may come from teaching and research institutions in France or abroad, or from public or private research centers.
L'archive ouverte pluridisciplinaire HAL, est destinée au dépôt et à la diffusion de documents scientifiques de niveau recherche, publiés ou non, émanant des établissements d'enseignement et de recherche français ou étrangers, des laboratoires publics ou privés. 


\title{
In Situ Generated Ruthenium-Arene Catalyst for Photoactivated Ring-Opening Metathesis Polymerization Through Photolatent $\mathrm{N}$ - Heterocyclic Carbene Ligand
}

\author{
Julien Pinaud, ${ }^{[a]}$ Thi Kim Hoang Trinh, ${ }^{[b]}$ David Sauvanier, ${ }^{[a]}$ Emeline Placet, ${ }^{[a]}$ Sriprapai Songsee,${ }^{[a]}$ \\ Patrick Lacroix-Desmazes, ${ }^{[\mathrm{a}]}$ Jean-Michel Becht, ${ }^{[\mathrm{b}]}$ Bassam Tarablsi, ${ }^{[\mathrm{b}]}$ Jacques Lalevée,${ }^{[\mathrm{b}]}$ Loïc \\ Pichavant, ${ }^{[c]}$ Valérie Héroguez, ${ }^{[c]}$ and Abraham Chemtob ${ }^{*[b]}$
}

\begin{abstract}
Bis(mesityl)imidazolium tetraphenylborate $\left(\mathrm{IMesH}^{+} \mathrm{BPh}_{4}{ }^{-}\right)$ can be synthesized in one step by anion metathesis between the corresponding imidazolium chloride and sodium tetraphenylborate. In the presence of 2-isopropylthioxanthone (sensitizer), IMes $\mathrm{N}$ heterocyclic carbene (NHC) ligand can be photogenerated under irradiation at $365 \mathrm{~nm}$ through coupled electron/proton transfer reactions. By combining this tandem NHC photogenerator system with metathesis inactive $\left[\mathrm{RuCl}_{2}(p-c y m e n e)\right]_{2}$ precatalyst, the highly active $\mathrm{RuCl}_{2}$ (p-cymene)(IMes) complex can be formed in situ, enabling a complete ring-opening metathesis polymerization (ROMP) of norbornene in the matter of minutes at room temperature. To the best of our knowledge, this is the first example of a photogenerated NHC. Its exploitation in photoROMP has resulted in a simplified process compared to current photocatalysts, because only stable commercial or easily synthesized reagents are required.
\end{abstract}

Since its discovery in the 1950s, olefin metathesis has evolved from a restricted use in petroleum cracking processes to the standard method for creating $\mathrm{C}-\mathrm{C}$ double bonds. Progress has been driven by a variety of increasingly advanced and well-defined olefin metathesis catalysts. ${ }^{[1]}$ These developments have predominantly benefited preparative organic chemistry and the synthesis of polymer materials. Many useful polymers such as poly(norbornene) or poly(dicyclopentadiene) can be prepared by ring-opening metathesis polymerization (ROMP), and have led to successful commercial applications as optical components high impact thermosets or shock absorbers. ${ }^{[2]}$ However, their implementation at industrial scale has been held back by air sensitivity and lack of processability under ambient conditions of most late transition metal-based catalysts. ${ }^{[3]}$ Designing ROMP catalysts in a way that allows the on-demand release of highly reactive transition metal alkylidenes is a very attractive goal to ease storage, handling, and processing. ${ }^{[4]}$ Compared to heat or $\mathrm{pH}$, UV-vis irradiation is certainly one of the most sought-after activating stimuli. ${ }^{[5]}$ Energy-saving, room-temperature process

[a] Dr. J. Pinaud, Dr. D. Sauvanier, E. Placet, S. Songsee, Dr. P. Lacroix-Desmazes

ICGM Univ Montpellier, CNRS, ENSCM, Montpellier, France E-mail: julien.pinaud@umontpellier.fr

[b] T. K. H. Trinh, Dr. J-M. Becht, Dr. B. Tarablsi, Prof. J. Lalevée, Dr. Abraham Chemtob

Institute of Mulhouse Material Science, UMR-CNRS 7361

University of Haute-Alsace

15 rue Jean Starcky, F-68057 Mulhouse Cedex, France

E-mail: abraham.chemtob@uha.fr

[c] Dr. V. Héroguez, Dr. L. Pichavant

Laboratoire de Chimie des Polymères Organiques - Ecole

Nationale Supérieure de Chimie, de Biologie et de Physique, UMR-

CNRS 5629

University of Bordeaux

16 avenue Pey-Berland, F-33607 Pessac Cedex, France

E-mail: valerie.heroguez@enscpb.fr

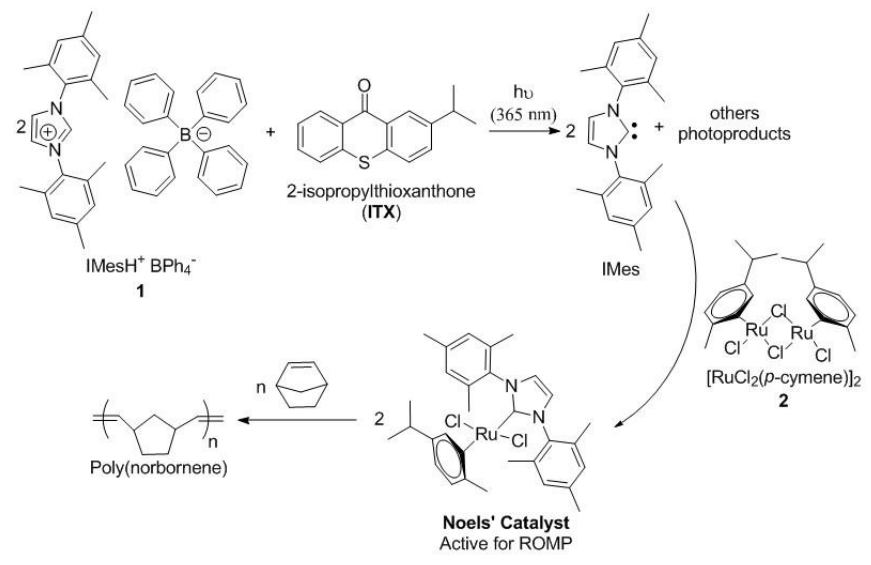

Scheme 1: Sensitized photogeneration of IMes NHC from imidazolium salt 1. Subsequent reaction with inactive $\mathrm{Ru}$ precatalyst 2 forms in situ the catalytically active Noels' catalyst triggering the ROMP of norbornene.

and spatio-temporal accuracy are some of the distinctive strengths of a UV-vis radiation induced polymerization. ${ }^{[6]}$ To date, however, only radical and cationic chain-growth processes have enabled photopolymerization to be harnessed as a technology capable of delivering innovative materials such as photoresists, industrial coatings, or inks. ${ }^{[7]}$

With the exception of photoredox catalysts, ${ }^{\left[{ }^{[8]}\right.}$ photoinduced ROMP (photoROMP) has been built on two types of organometallic catalysts whether or not containing an alkylidene moiety from the beginning. ${ }^{[3]}$ Currently, the most common strategy is to start from a preformed $\mathrm{Ru}$ alkylidene complex made inactive by a sound choice of chelating ligands ${ }^{[9]}$ or electron-rich carbene moieties. ${ }^{[10]}$ Activation is driven subsequently by photoinduced ligand dissociation/rearrangement ${ }^{[9 a]}$ or isomerization reactions. ${ }^{\text {[9b-f] }}$ Originally, the first photolatent precatalysts were photosensitive alkylidene-free complexes in which the propagating metal carbene species was generated in situ by a photodisplacement of the ligand. ${ }^{[11]}$ Despite the variety of precatalysts and photochemical mechanisms, very few systems can boast full thermal stability and high activity at room temperature. In almost all cases, photolysis relies on the direct excitation of the precatalyst bearing a photoactive group.

In an effort to improve catalyst performance, versatility, latency and ease of synthesis, we believed that an indirect activation method of the precatalyst based on an exogenous photosensitive species could provide significant advantages. Previous work has shown that a metathesis inactive $\mathrm{Ru}$ alkylidene complex could be converted into an active system by a commercial photoacid generator. ${ }^{[12]}$ Taking a distinctive indirect approach, we report our efforts to develop a highly active photoinitiated catalytic system based on the combination of a photosensitive imidazolium salt (1) acting as a 


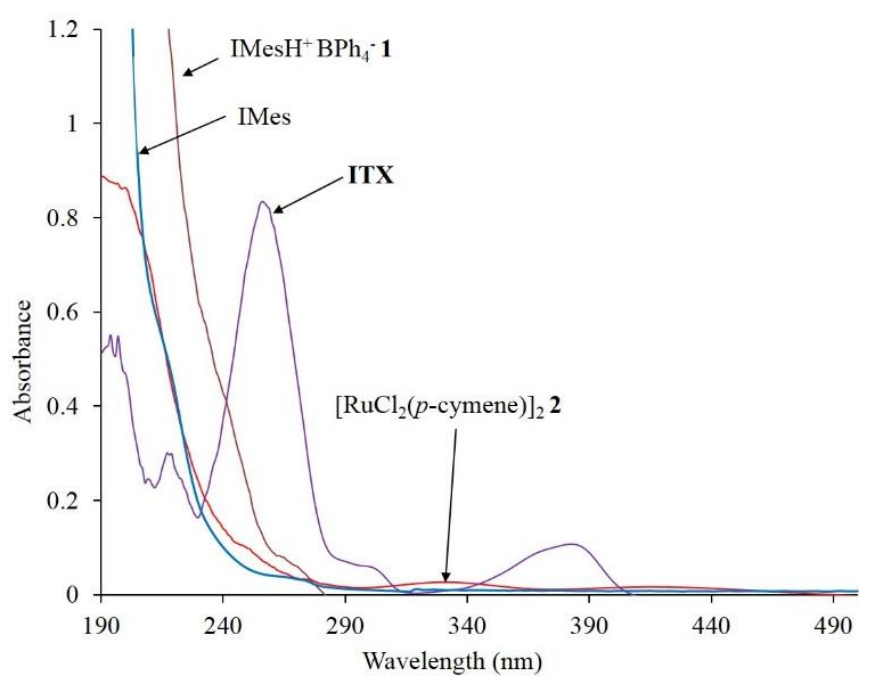

Figure 1: UV-vis absorption spectra of IMesH ${ }^{+} \mathrm{BPh}_{4}^{-}$, IMes, ITX and $\left[\mathrm{RuCl}_{2}(p\right.$ cymene $)]_{2}$ in acetonitrile $\left(2.0 \times 10^{-5} \mathrm{M}\right)$.

photogenerator of $\mathrm{N}$-heterocyclic carbene $(\mathrm{NHC})$ ligand and the well-known inactive $\left[\mathrm{RuCl}_{2}(p \text {-cymene) }]_{2}\right.$ dimer (2) (Scheme 1). Indeed, It is recognized that the simple reaction of $\mathrm{Ru}$ precatalyst $\mathbf{2}$ with a suitable $\mathrm{NHC}$ imidazolidene ligand (such as 1,3-bis(mesityl)imidazol-2-ylidene, abbreviated as IMes) is a means to generate in situ the highly active ruthenium-arene complex $\mathrm{RuCl}_{2}(p$-cymene)(NHC), also known as Noels' catalyst. ${ }^{[13]}$ Obviously, part of the challenge lies in the design of an NHC photogenerator. So far, all latent NHCs are triggered thermally or mechanically, ${ }^{[14]}$ and the synthesis of an efficient photolatent $\mathrm{NHC}$ has yet to be developed.

To photogenerate the well-established IMes, we propose the imidazolium tetraphenylborate salt $\mathrm{IMesH}^{+} \mathrm{BPh}_{4}{ }^{-} \mathbf{1}$ as a potential $\mathrm{NHC}$ photogenerator. The photochemistry of tetraarylborates has been well examined, ${ }^{[15]}$ and previous work showed its utilization as a photobase generator via a photoinduced proton transfer reaction. ${ }^{[16]}$ For its synthesis, simple treatment in ethanol of $\mathrm{NaBPh}_{4}$ with the commercial imidazolium salt $\mathrm{IMesH}^{+} \mathrm{Cl}^{-}$ resulted in a quantitative anion exchange to provide the desired photolatent NHC cleanly and in excellent yield $(94 \%) .{ }^{[1]}$ Compound 1 appears as white crystals with a melting point at $212{ }^{\circ} \mathrm{C}$ and a decomposition threshold at $292{ }^{\circ} \mathrm{C}$ (see a complete characterization in Fig. S1 of the supporting information). Its electronic absorption (Figure 1) spans only the UV-C region (100-280 nm) with an intense peak at $198 \mathrm{~nm}\left(\varepsilon_{198}\right.$ $\left.=1.38 \times 10^{5} \mathrm{M}^{-1} \mathrm{~cm}^{-1}\right)$ and a weak peak at $254 \mathrm{~nm}\left(\varepsilon_{254}=7.30 \times\right.$ $10^{3} \mathrm{M}^{-1} \mathrm{~cm}^{-1}$ ) (Figure 1). A comparison with $\mathrm{NaBPh}_{4}$ and $\mathrm{IMesH}^{+}$ $\mathrm{Cl}^{-}$salts (Fig. S2) clearly established that both the anion $\left(\mathrm{BPh}_{4}{ }^{-}\right)$ and cation $\left(\mathrm{IMesH}^{+}\right)$of $\mathbf{1}$ are chromophores. However, an absorption range limited to short wavelengths represents a drawback for a broad use of $\mathbf{1}$ in photopolymerization due to competitive absorption with most cyclic olefin monomers. To extend spectral sensitivity at higher wavelengths, the photodecomposition of $\mathbf{1}$ was sensitized by 2 isopropylthioxanthone (ITX). ITX absorbs within the UV-A range $(320-400 \mathrm{~nm}$, Figure 1), which is the most suitable for photochemistry. Through its broad and intense absorption band at $365 \mathrm{~nm}\left(\varepsilon_{365}=4.5 \times 10^{4} \mathrm{M}^{-1} \mathrm{~cm}^{-1}\right)$, a wider range of radiation sources can be used, in particular the near UV light-emitting

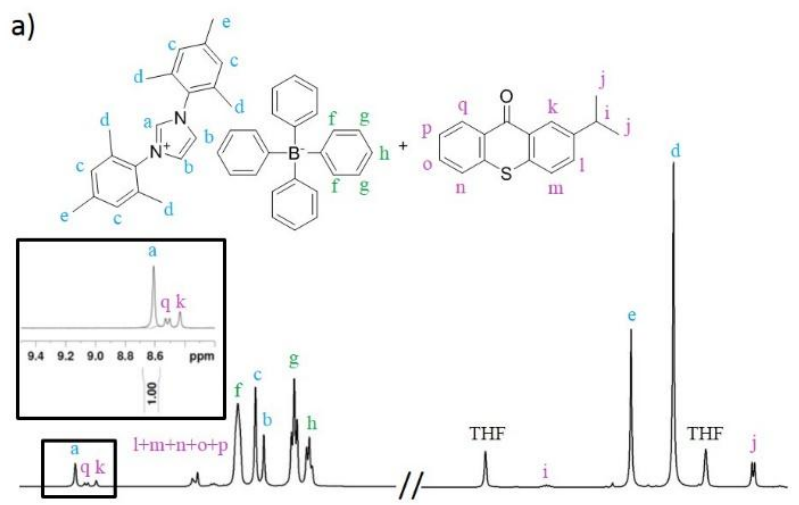

b)
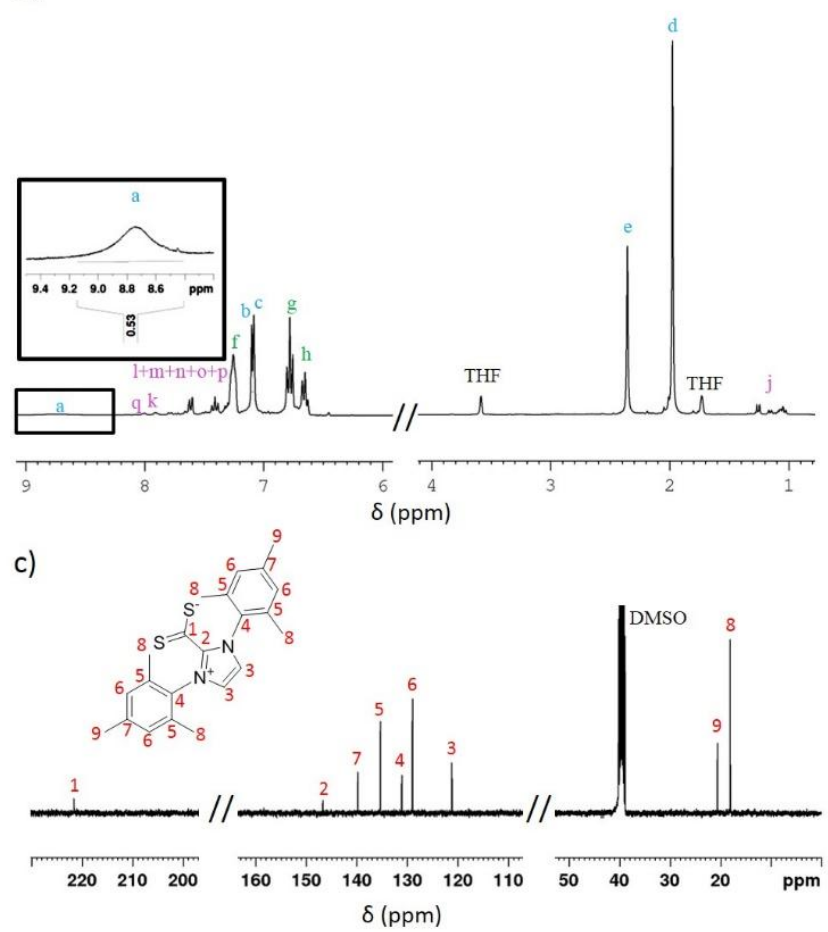

Figure 2: ${ }^{1} \mathrm{H}$ NMR spectra of $1 / \mathrm{ITX}$ (2/1 eq.) mixture in THF- $d_{8}(0.12 \mathrm{M}$ relative to 1): (a) before UV exposure, (b) after $10 \mathrm{~min}$ irradiation at $365 \mathrm{~nm}$ $\left.(0.12 \mathrm{~mW} \mathrm{~cm})^{-2}\right)$ in a Rayonet巴 ${ }^{8}$ photochemical reactor; (c) ${ }^{13} \mathrm{C}$ NMR spectra in DMSO- $d_{6}$ of the precipitate recovered after addition of $\mathrm{CS}_{2}$. Inserts: deprotonation yields were obtained by comparing the integrated area of the $H_{a}$ proton resonance versus the methyl protons $\mathrm{H}_{d}$ used as internal standard.

diodes (LEDs), allowing very energy efficient, reliable, and simple generation of UV radiation between 365 and $395 \mathrm{~nm}$. Also noteworthy is that ITX has a limited absorption overlap with $\mathrm{Ru}$ precatalyst and that the expected NHC (IMes) is inert to incident UV-A wavelengths as it begins to absorb below $280 \mathrm{~nm}$ $\left(\varepsilon_{198}=9.7 \times 10^{4} \mathrm{M}^{-1} \mathrm{~cm}^{-1}\right)$. Herein, we investigate the in situ photogeneration of the highly active $\mathrm{RuCl}_{2}$ (p-cymene)(IMes) catalyst through a three-component system: PhotoNHC 1/ Ru precatalyst 2 / Sensitizer ITX (Scheme 1). Such a combination requires only stable commercial or easily synthesized reagents, thus leading to a simple and straightforward photoROMP procedure. First, the ability to photogenerate $\mathrm{NHCs}$ was assessed by irradiating a THF- $d_{8}$ solution of $1 /$ ITX (2/1 eq) at 


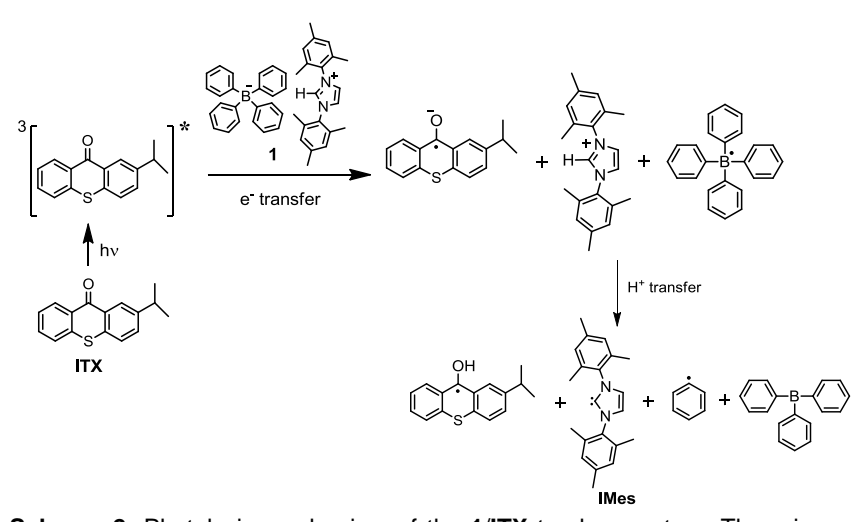

Scheme 2: Photolysis mechanism of the 1/ITX tandem system. The primary step is the photochemically induced electron transfer from $\mathrm{BPh}_{4}{ }^{-}$to triplet ITX. The resulting intermediate carbon anion may abstract a proton from $\mathrm{ImesH}^{+}$to release the free NHC IMes. Boranyl and ketyl radicals are the other photoproducts. Carbon-boron cleavage of the boranyl radical may generate triphenylborane and a phenyl radical as described in the literature. ${ }^{[18]}$

$365 \mathrm{~nm}$ for $10 \mathrm{~min}$, followed by ${ }^{1} \mathrm{H}$ NMR spectroscopy analysis (Figure 2). Proton $\mathrm{H}_{\mathrm{a}}(\delta=8.63 \mathrm{ppm}$, Figure 2a) on carbon 2 adjacent to the two nitrogen atoms disappeared partially upon irradiation (53\%, Figure $2 \mathrm{~b}$ ), suggesting a photoinduced proton transfer reaction. Deprotonation was also demonstrated in other solvents $\left(\mathrm{CD}_{2} \mathrm{Cl}_{2}\right.$ and acetonitrile- $d_{3}$, see Fig. S3 and S4). However, direct detection of the in situ formed $\mathrm{NHC}$ was more challenging because the position of the other protons $\left(\mathrm{H}_{\mathrm{b}-\mathrm{e}}\right)$ of $\mathrm{IMesH}^{+}$is almost identical to the free IMes (Fig S5), and therefore, there is no expected shift after irradiation. To determine the precise structure of the generated species, an indirect identification method was undergone by reacting the asirradiated medium with $\mathrm{CS}_{2}$. The resultant red precipitate formed in THF- $d_{8}$ was readily collected, then dissolved in DMSO- $d_{6}$. The ${ }^{13} \mathrm{C}$ spectrum (Figure 2c) displayed the characteristic signals of the pure zwitterionic adduct IMes- $\mathrm{CS}_{2}$, thereby evidencing the formation of the targeted IMes NHC. Capitalizing on the Brönsted basicity of $\mathrm{NHC}\left(\mathrm{pK}_{\mathrm{a}}\left(\mathrm{IMes} / \mathrm{IMesH}^{+}\right)=20.8\right.$ at $25^{\circ} \mathrm{C}$ in water ${ }^{[19]}$, the amount of released $\mathrm{NHC}$ was evaluated by acid/base titration using phenol red $\mathrm{pH}$ indicator as titrant (Fig. S6). A maximum yield of $50 \%$ was achieved after $5 \mathrm{~min}$ of irradiation (see SI for experimental details).

With an emission spectrum restricted to UV-A, removing ITX completely suppressed the photoactivity of $\mathrm{IMesH}^{+} \mathrm{BPh}_{4}^{-}$. This result confirmed the major role of the photoexcited triplet state ITX in a sensitized reaction. With respect to the reaction mechanism, triplet-triplet energy transfer from ${ }^{3} \mathrm{ITX}^{*}$ to ${ }^{3}$ PhotoNHC ${ }^{*}$ can be discarded since the following triplet energy order, $\mathrm{E}_{\mathrm{T}}\left(\mathrm{BPh}_{4}{ }^{-}\right)>\mathrm{E}_{\mathrm{T}}(\mathrm{ITX})$, was determined by conventional computational procedure. On the other hand, the tetraphenylborate anion was proved to have electron donor properties. ${ }^{[18]}$ Therefore, it is more likely that an electron transfer from $\mathrm{BPh}_{4}^{-}$to ${ }^{3} \mathrm{ITX} X^{*}$ may take place as a primary step, to form the radical anion intermediate on the photoinitiator. Subsequent proton transfer from $\mathrm{IMesH}^{+}$may yield IMes and ketyl radical on ITX (- $\left.\mathrm{C}^{\bullet}(\mathrm{OH})-\right)$. Based on a coupled electron/proton transfer, our tentative mechanism (Scheme 2 ) is close to that of type II radical photoinitiators $^{[20]}$ which are mixtures of hydrogen acceptors (oxidant, e.g. ketone) and donors (reductant, e.g. tertiary amine). The possibility of electron-transfer upon
Table 1. Photopolymerization results of NB using $1 / 2 /$ ITX photoinitiating system in $\mathrm{CD}_{2} \mathrm{Cl}_{2}$ (1.06 $\mathrm{M}$, relative to $\left.\mathrm{NB}\right)$. Irradiation was performed in a Rayonet $\AA$ photochemical reactor $\left(365 \mathrm{~nm}, 0.12 \mathrm{~mW} \mathrm{~cm}{ }^{-2}, 10 \mathrm{~min}\right.$ irradiation)

\begin{tabular}{|c|c|c|c|c|c|c|}
\hline Entry & $\begin{array}{c}\text { 1:2:ITX:NB } \\
\text { Eq }\end{array}$ & $\begin{array}{c}\text { Conv. }{ }^{\text {[a] }} \\
\%\end{array}$ & $\begin{array}{l}\mathrm{M}_{\mathrm{n}-\mathrm{th}}{ }^{[\mathrm{b}]} \\
\mathrm{kg} \mathrm{mol}^{-1}\end{array}$ & $\begin{array}{l}\mathrm{M}_{\mathrm{n}-\mathrm{SEC}}{ }^{[\mathrm{C}]} \\
\mathrm{kg} \mathrm{mol}^{-1}\end{array}$ & $\theta^{[\mathrm{CT}}$ & $\sigma_{\text {cis }}^{\left[{ }^{[d]}\right.}$ \\
\hline$a$ & $10: 1: 5: 540$ & 100 & 25.4 & 288.4 & 1.49 & 0.50 \\
\hline$b$ & $10: 1: 1: 540$ & 100 & 25.4 & 188.9 & 1.87 & 0.45 \\
\hline C & $10: 0: 1: 540$ & 0 & - & - & - & - \\
\hline$d$ & $0: 1: 5: 540$ & 19 & 25.4 & 357.5 & 1.90 & 0.26 \\
\hline $\mathrm{e}$ & $10: 1: 0: 540$ & 42 & 25.4 & 94.7 & 1.70 & 0.22 \\
\hline
\end{tabular}

[a] Determined by ${ }^{1} \mathrm{H}$ NMR after 10 min UV irradiation. [b] Theoretical number average molar mass $\mathrm{M}_{\mathrm{n} \text {-th }}=$ Conv. $\times \frac{[N B] \times M_{N B}}{2 \times[2]}$ [c] Experimental number average molar mass obtained after reaching full monomer conversion and determined by triple detection SEC. [d] Fraction of cis double bonds as determined by ${ }^{1} \mathrm{H}$ NMR

electronic excitation of the oxidant (ITX) was supported by a number of evidences. According to the Rehm-Weller equation, the free energy change for an electron transfer from $\mathrm{BPh}_{4}{ }^{-}$to ${ }^{3} \mathrm{ITX}^{*}$ is favorable $\left(\Delta \mathrm{G}_{\mathrm{et}}=-0.13 \mathrm{eV}\right)$, but weak. Conversely, a photooxidation of ${ }^{3} \mathrm{ITX}{ }^{*}$ by $\mathrm{IMesH}^{+}$is not thermodynamically feasible $\left(\Delta \mathrm{G}_{\mathrm{et}}=+0.72 \mathrm{eV}\right)$. Quenching of ${ }^{3} \mathrm{ITX}{ }^{*}$ in the presence of 1 was also proved by Laser Flash Photolysis (LFP) experiments in acetonitrile (Nd-YAG laser excitation at $355 \mathrm{~nm}$ ). An interaction rate constant was determined by measuring the rate of triplet decay at $600 \mathrm{~nm}$ from Stern-Volmer plots (Fig. S7) The estimated quenching rate of $4 \times 10^{7} \mathrm{M}^{-1} \mathrm{~s}^{-1}$ was lower than that encountered in the known photochemistry of ${ }^{3} \mathrm{ITX}^{*} / \mathrm{amine}$ systems, ranging usually from $10^{8}$ to $10^{9} \mathrm{M}^{-1} \mathrm{~s}^{-1} \cdot{ }^{[20]}$ Interestingly, $\mathrm{IMesH}^{+} \mathrm{BPh}_{4}^{-}$(1) and $\mathrm{NaBPh}_{4}$ showed nearly identical quenching rates, suggesting that $\mathrm{BPh}_{4}{ }^{-}$serves as an efficient electron donor and that the cation $\mathrm{IMesH}^{+}$is not involved in the first step of electron transfer. Accordingly, no deprotonation was observed by ${ }^{1} \mathrm{H}$ NMR spectroscopy when 1 was replaced by IMesH $\mathrm{H}^{+} \mathrm{Cl}^{-}$(Fig. S8).

Subsequent efforts were directed toward exploring the catalytic activity of the three-component system 1/2/ITX in ROMP solution reaction of common monomers such as norbornene (NB). Irradiation was performed in a conventional Rayonet ${ }^{\circledR}$ photochemical reactor $\left(\lambda_{\max }=365 \mathrm{~nm}\right)$ at room temperature. As shown in Table 1 for NB, excellent conversions were achieved after only $10 \mathrm{~min}$ of irradiation (entry a), suggesting the successful formation of the highly active ruthenium-arene complex bearing an NHC ligand. Even with lower loadings of ITX (entry b), conversion was maintained at a very high level. Molecular weights were higher than those predicted, which is indicative of incomplete catalyst activation. ${ }^{[11 c]}$ Polymer with relatively narrow dispersity values $(\theta=1.5)$ were obtained. While irradiation of a solution devoid of $\mathrm{Ru}$ dimer resulted in no reaction (entry c), a small conversion was observed without 1 ( $19 \%$, entry d) or the sensitizer (42\%, entry e). Clearly, a direct excitation of the Ru precatalyst 2 at $365 \mathrm{~nm}$ is possible (Figure 1 ), which could generate a small amount of active species without the assistance of $\mathrm{NHC}$. In this case, the required ROMP. active metal-alkylidene fragment may originate from a sequence involving a first photoinduced decoordination of the ${ }^{6} \eta$ arene ligand to release an unsaturated $\mathrm{Ru}$ species able to react with the alkene substrate. Such secondary initiation mechanism has been already reported, but only with mononuclear Ru complex e.g. $\mathrm{RuCl}_{2}$ (arene)(NHC). ${ }^{[13]}$ However, it proceeds only with highly 


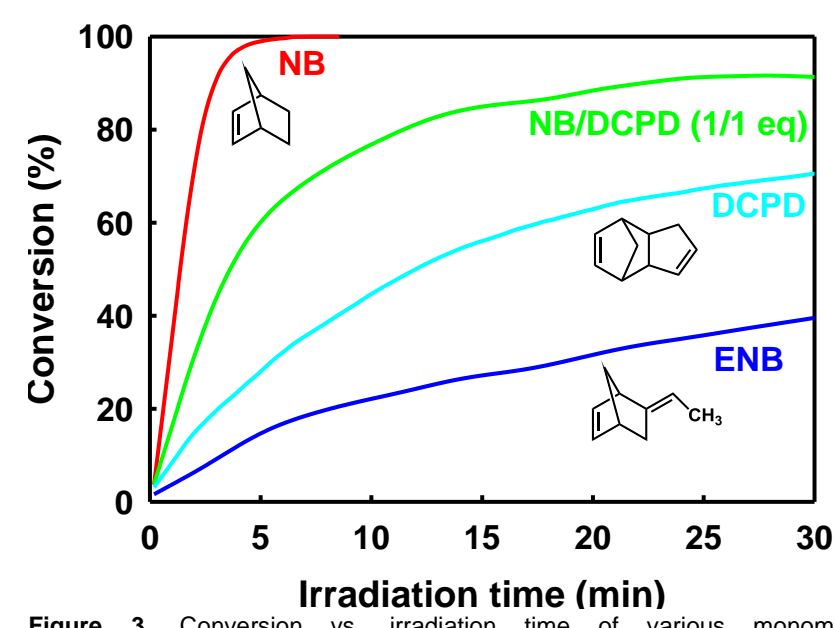

Figure 3. Conversion vs. irradiation time of various monomers. 1:2:ITX:Monomer (10:1:5:510 eq) in $\mathrm{CH}_{2} \mathrm{Cl}_{2}$ (1 $\mathrm{M}$, relative to monomer). Irradiation: $365 \mathrm{~nm}$ LED (irradiance: $65 \mathrm{~mW} \mathrm{~cm}^{-2}$ ).

active olefinic substrates such as NB, because no reaction was observed with DCPD. The co-existence of two distinct photochemical pathways was supported by differences in poly $(\mathrm{NB})$ cis fraction. In the presence of $\mathbf{1}$ (entries a-b), $\sigma_{\text {cis }}(\approx$ 0.5 ) was very similar to that found in the corresponding polymer prepared by the action of Ru-NHC complex, ${ }^{[21]}$ thereby suggesting the formation of the same ROMP catalyst. Conversely, a lower $\sigma_{\text {cis }}$ was obtained without 1 (entries d-e), which agrees with the formation of another propagating species giving rise to a kinetically distinct conformation.

Additionally, photopolymerization kinetics were investigated by real-time FTIR spectroscopy. To achieve this, a $365 \mathrm{~nm}$ LED spot source $\left(65 \mathrm{~mW} \mathrm{~cm}^{-2}\right.$ at $\lambda_{\max }=365 \mathrm{~nm}$ ) was focused through a light guide on a conventional IR liquid transmission cell containing the NB reactive solution. Reaction progress was monitored in situ by following the decreasing $\mathrm{C}=\mathrm{C}$ stretching mode at $1566 \mathrm{~cm}^{-1}$, only visible for NB and not the resultant polyalkenamer (Figure 3). Using the three-component 1/2/ITX system, full conversion of NB was accomplished in $\mathrm{CH}_{2} \mathrm{Cl}_{2}$ after 4 min. Upon removing 1, less than $5 \%$ of NB was converted after the same period of time, confirming the key role played by the $\mathrm{NHC}$ in the generation of a highly reactive ROMP catalyst. With the monofunctional monomer 5-ethylidene-2-NB (ENB), consumption was reduced to $40 \%$ after 30 min of irradiation. The method was finally expanded to multifunctional cyclic olefins in an attempt to develop a promising photoROMP UV curing technology. Dicylopentadiene (DCPD) resulted in $70 \%$ conversion while a copolymerization with NB in a 1 to 1 ratio (mol. eq.) increased conversion up to $90 \%$.

In conclusion, the easily synthesized $\mathrm{IMesH}^{+} \mathrm{BPh}_{4}^{-}$salt has proved to release the IMes-type NHC under UV-irradiation at $365 \mathrm{~nm}$ when sensitized by ITX, making it the first example of an $\mathrm{NHC}$ photogenerator. In combination with $\left[\mathrm{RuCl}_{2}(p \text {-cymene })\right]_{2}$, the three-component system $\mathbf{1 / 2} / \mathbf{I T X}$ has allowed the fast photoROMP of NB at room temperature. The design of photosensitive imidazolium salt offers facile synthesis and affordable raw materials. There are other potential advantages: changing the imidazolium cation to broaden the structural diversity of photogenerated NHCs, or the structure of the anion can help shift the absorption towards near UV-vis region. These attributes and potentialities open new avenues, not only for photoROMP, but also to develop novel NHC organocatalyzed photoreactions and photopolymerizations.

\section{Acknowledgements}

Financial support by the French National Research Agency (ANR program: DS0304 2016, contract number: ANR-16-CE070016) and the French Ministry of Research (doctoral grant of EP) are gratefully acknowledged.

Keywords: N-heterocyclic carbenes • photopolymerization • photochemistry $\cdot$ metathesis $\cdot$ ROMP

[1] A. H. Hoveyda, A. R. Zhugralin, Nature 2007, 450, 243-251.

[2] J. C. Mol, J. Mol. Catal. A: Chem. 2004, 213, 39-45.

[3] S. Naumann, M. R. Buchmeiser, Macromol. Rapid Commun. 2014, 35, 682-701.

[4] a) K. A. Ogawa, A. E. Goetz, A. J. Boydston, Synlett 2016, 27, 203-214; b) S. Monsaert, A. L. Vila, R. Drozdzak, P. Van Der Voort, F. Verpoort, Chem. Soc. Rev. 2009, 38, 3360-3372.

[5] a) Y. Vidavsky, N. G. Lemcoff, Beilstein J. Org. Chem. 2010, 6, 11061119; b) C. E. Diesendruck, O. Iliashevsky, A. Ben-Asuly, I. Goldberg, N. G. Lemcoff, Macromol. Symp. 2010, 293, 33-38; c) O. Eivgia, N. G. Lemcoff, Synth. 2017, 49, DOI: 10.1055/s-0036-1589113; d) O. Reany, N. G. Lemcoff, Pure Appl. Chem. 2017, 89, 829-840.

[6] W. Schnabel, in Polymers and Light, Wiley-VCH Verlag, 2007, pp. 273 304.

[7] R. Schwalm, in UV Coatings, Elsevier, Amsterdam, 2007, pp. 19-61.

[8] a) A. E. Goetz, A. J. Boydston, J. Am. Chem. Soc. 2015, 137, 7572-7575; b) K. A. Ogawa, A. E. Goetz, A. J. Boydston, J. Am. Chem. Soc. 2015 137, 1400-1403.

[9] a) D. Wang, J. Unold, M. Bubrin, I. Elser, W. Frey, W. Kaim, G. Xu, M. R Buchmeiser, Eur. J. Inorg. J. 2013, 2013, 5462-5468; b) A. Ben-Asuly, A. Aharoni, C. E. Diesendruck, Y. Vidavsky, I. Goldberg, B. F. Straub, N. G. Lemcoff, Organometallics 2009, 28, 4652-4655; c) E. Levin, S. Mavila, O. Eivgi, E. Tzur, N. G. Lemcoff, Angew. Chem. Int. Ed. 2015, 54, 12384 12388; d) R. L. Sutar, E. Levin, D. Butilkov, I. Goldberg, O. Reany, N. G Lemcoff, Angew. Chem. Int. Ed. 2016, 55, 764-767; e) A. J. Teator, H. L. Shao, G. Lu, P. Liu, C. W. Bielawski, Organometallics 2017, 36, 490-497; f) V. Sashuk, O. Danylyuk, Chem. Eur. J. 2016, 22, 6528-6531.

[10] R. A. Weitekamp, H. A. Atwater, R. H. Grubbs, J. Am. Chem. Soc. 2013, 135, 16817-16820.

[11] a) P. A. vanderSchaaf, A. Hafner, A. Muhlebach, Angew. Chem. Int. Ed. 1996, 35, 1845-1847; b) A. Hafner, A. Muhlebach, P. A. vanderSchaaf, Angew. Chem. Int. Ed. 1997, 36, 2121-2124; c) L. Delaude, A. Demonceau, A. F. Noels, Chem. Commun. 2001, 986-987; d) L. Delaude, M. Szypa, A. Demonceau, A. F. Noels, Adv. Synth. Cat. 2002, 344, 749756; e) D. Wang, K. Wurst, W. Knolle, U. Decker, L. Prager, S. Naumov, M. R. Buchmeiser, Angew. Chem. Int. Ed. 2008, 47, 3267-3270; f) C. Ernst, C. Elsner, A. Prager, B. Scheibitz, M. R. Buchmeiser, J. Appl. Polym. Sci. 2011, 121, 2551-2558; g) D. Wang, K. Wurst, M. R. Buchmeiser, Chem. Eur. J. 2010, 16, 12928-12934; h) D. Wang, J. Unold, 
M. Bubrin, W. Frey, W. Kaim, M. R. Buchmeiser, Chemcatchem 2012, 4, 1808-1812; i) A. Hafner, P. A. van der Schaaf, A. Muhlebach, P. Bernhard U. Schaedeli, T. Karlen, A. Ludi, Prog. Org. Coat. 1997, 32, 89-96.

[12] a) B. K. Keitz, R. H. Grubbs, J. Am. Chem. Soc. 2009, 131, 2038-2039; b) A. Y. Khalimon, E. M. Leitao, W. E. Piers, Organometallics 2012, 31, 5634-5637.

[13] L. Delaude, A. Demonceau, Dalton Trans. 2012, 41, 9257-9268.

[14] a) S. Naumann, M. R. Buchmeiser, Cat. Sci. Techno. 2014, 4, 2466-2479; b) M. Fevre, J. Pinaud, Y. Gnanou, J. Vignolle, D. Taton, Chem. Soc. Rev. 2013, 42, 2142-2172.

[15] a) J. D. Wilkey, G. B. Schuster, J. Org. Chem. 1987, 52, 2117-2122; b) J. L. R. Williams, J. C. Doty, P. J. Grisdale, R. Searle, T. H. Regan, G. P. Happ, D. P. Maier, J. Am. Chem. Soc. 1967, 89, 5153-5157; c) A. Pelter, R. T. Pardasani, P. pardasani, Tetrahedron 2000, 56, 7339-7369.
[16] X. Sun, J. P. Gao, Z. Y. Wang, J. Am. Chem. Soc. 2008, 130, 8130-8131. [17] a) E. Alcalde, I. Dinares, A. Ibanez, N. Mesquida, Chem. Commun. 2011, 47, 3266-3268; b) E. Alcalde, I. Dinares, A. Ibanez, N. Mesquida, Molecules 2012, 17, 4007-4027.

[18] S. Chatterjee, P. D. Davis, P. Gottschalk, M. E. Kurz, B. Sauerwein, X. Yang, G. B. Schuster, J. Am. Chem. Soc. 1990, 112, 6329-6338.

[19]E. M. Higgins, J. A. Sherwood, A. G. Lindsay, J. Armstrong, R. S. Massey, R. W. Alder, A. C. O'Donoghue, Chem. Commun. 2011, 47, 1559-1561.

[20] S. Dadashi-Silab, C. Aydogan, Y. Yagci, Polym. Chem. 2015, 6, 65956615.

[21] L. Delaude, A. Demonceau, A. F. Noels, Curr. Org. Chem. 2006, 10, 203215. 
Entry for the Table of Contents (Please choose one layout)

We choose Layout 1

\section{Graphical Abstract:}

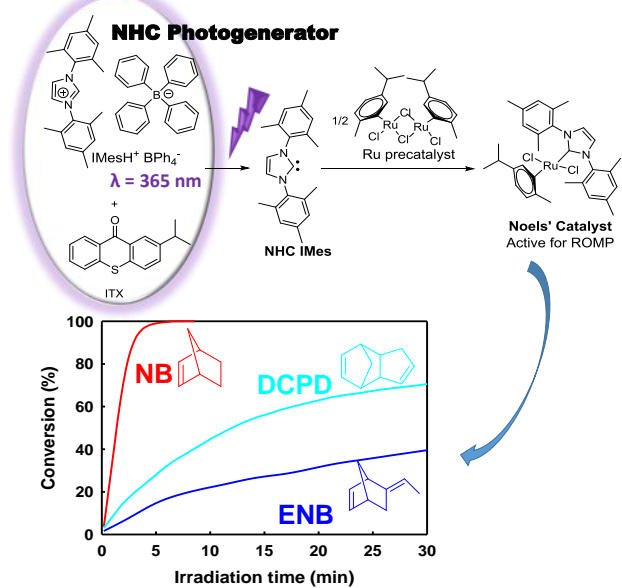

Text for table of content: We describe the first N-heterocyclic carbene (NHC) photogenerator consisting of an air-stable imidazolium tetraphenylborate salt as protected form of NHCs and isopropylthioxanthone (ITX) as sensitizer. A NHC-coordinated complex effective at photoROMP can be made in situ by subsequent reaction with the conventional ruthenium precatalyst $\left[\mathrm{RuCl}_{2}(p \text {-cymene })\right]_{2}$.

Keywords: Carbene Ligands, Photochemistry, Ring-Opening Polymerization, N-Heterocyclic Carbene, Ruthenium 